IRA-International Journal of Management \& Social Sciences

ISSN 2455-2267; Vol.04, Issue 03 (2016)

Pg. no. 633-641

Institute of Research Advances

http://research-advances.org/index.php/RAJMSS

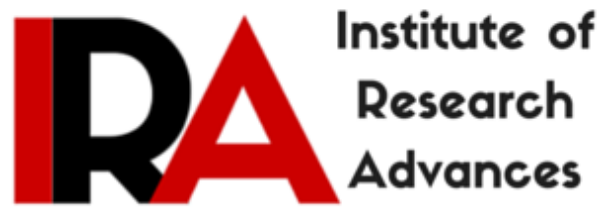

\title{
Applying Analytic Hierarchy Process to Establish Garbage Man Selection System for Taiwan
}

\author{
Hwai-Hui $\mathrm{Fu}^{1}$, Li-Jhen Chen ${ }^{2}$ \\ ${ }^{1,2}$ Shu-Te University \\ 59, Hun Shan Road, Yen Chau, \\ Kaohsiung City, 82445, Taiwan.
}

Type of Review: Peer Reviewed.

DOI: http://dx.doi.org/10.21013/jmss.v4.n3.p14

\section{How to cite this paper:}

Fu, H., \& Chen, L. (2016). Applying Analytic Hierarchy Process to Establish Garbage Man Selection System for Taiwan. IRA-International Journal of Management \& Social Sciences (ISSN 2455-2267), 4(3), 633-641. doi:http://dx.doi.org/10.21013/jmss.v4.n3.p14

(C) Institute of Research Advances

(c) EY-NC

This work is licensed under a Creative Commons Attribution-Non Commercial 4.0 International License subject to proper citation to the publication source of the work.

Disclaimer: The scholarly papers as reviewed and published by the Institute of Research Advances (IRA) are the views and opinions of their respective authors and are not the views or opinions of the IRA. The IRA disclaims of any harm or loss caused due to the published content to any party. 


\begin{abstract}
Global have attached very great importance to environmental protection in these decades. In this study, a new procedure using an Analytic Hierarchy Process (AHP) with Affinity Diagram to set up measurable indicators and determine their weights for garbage man selection system. Eighteen experts, including eleven officials and seven experienced garbage man, were incited to participate in this survey. To aggregate the result, job attitude gains the most weight (0.447), followed by garbage treatment knowledge (0.299) and physical fitness (0.254). The main contributions of this paper are: (1) to integrate the AHP with Affinity Diagram that converts the subjective cognitions of groups including officials and experienced garbage man and (2) to provide the governments with criteria to formulate reasonable regulations for garbage man selection system.
\end{abstract}

Keywords: Environmental protection, Analytic Hierarch Process (AHP), Affinity Diagram, Garbage man

\title{
Introduction
}

Now a day, human pursuit of economic development and advance of science and technology, over use natural resources which not only destroyed the environment but caused a number of garbage increasing sharply [1]. Built an effective waste management system reduce the damage of environment, this is the most important issue from today [2].

Implementation of "garbage classification and recycling" which is you and I can do to contribute to the mother earth. If the garbage is not classification before incineration, government will not be able to handle whole bunch of garbage. Currently, the waste is broadly divided into five categories are general garbage, recyclable garbage, kitchen waste, electronic waste. But people are not implemented classification the waste frequently, it causes the garbage man exposed to physical, chemical, biological and the danger of operate procedure. Therefore, recruiting a garbage man must considerate multifaceted conditions.

During the organize countries' garbage man selection system, we found out that now recruiting a garbage man have a complex process. For example, written examination, physical fitness test. But there are many different standards and weights in different counties. Since the "garbage classification and recycling" is an important issue, so the garbage man selection is particularly important.

Through the implementation of this program not only can put what you have learned into practice but also the garbage man selection system as a standard can offer to every country.

\section{Literature review}

This research paper uses Analytic Hierarchy Process method to investigate the collection system of garbage man. And literature sorting divided into five parts. First part is the definition of recruitment. Second part is the definition of environmental protection. Third part is garbage and recycling. Fourth part is the definition of work attitude. And last part is the definition of physical fitness.

\section{The importance of Recruitment \& Selection}

Recruitment is the process of attract candidates for job vacancies. Using any source attract capable people to apply the job [3]. Selection is based on recruitment. Selection's results reflect to the success of the recruitment and Value. So, recruitment is quite important. Because the more people apply, enterprise will have higher chance to select outstanding and suitable talented person.

The purpose of selection is apportioning job by one's operating characteristics (Ability, Experience) and making a great collocation with duties demand. And, if administration doesn't collocation well with the two items, workers will often have poor performance and job satisfaction on the job [4]. On the other words, selecting a higher the adaptability employee, it means employee's ability and experience is similar with job demands. In this situation, employees will also be handy to work. Also, 
it will bring a high degree of job satisfaction to employees, and improve employee performance on the job. And it is a benefit for an enterprise. On the above is shows the importance of selection.

\section{The definition of environmental protection}

Environmental protection is using any kind of ways to maintain or restore the quality of the environment. For example, preventing or reducing pollutant emissions of pollutants in the environment [5]. And, environmental protection will not hamper a countries' national competitiveness, it is not only a countries' economic performance but also a topic the world must pay attention [6].

\section{Garbage classification and recycling}

The definition of Recycling is recovered materials brought back into the value chain utilized as secondary raw materials" [7] on the other words, Recycling is the process by which waste materials are diverted from the waste stream, sorted and used to produce new products [8].

Economic development improves human's living standards, increase the consumption, lead to the number of garbage increase constantly.

Recycling is the process by which waste materials are diverted from the waste stream, sorted and used to produce new products.

Garbage is divided into thirteen categories such as battery, electronic waste, glass, metal, organic waste, paper and cardboard, plastic, rubber, fluorescent lamp, clothes, furniture, woods and toner cartridge $[8,9]$.

\section{Job attitude}

Attitudes are the feelings and beliefs that greatly decided how worker will perceive their environment, to promise themselves to take actions, and eventually behave [10].

Job attitude is one of the oldest, most popular and most influential psychological research projects. It is using to evaluate one's to one's job's feeling and beliefs then affect to one's job [11]. In addition, attitude shape a mental set that influence how we view things. It has an impact on how we view and judge our work environment. [10] Moreover, Robbins [12] believe that personal job attitude is the most important thing in the organization, because attitude will affect their work behavior directly. So came up with personal job attitude is the work engagement, job satisfaction, and organizational commitment, these three dimension.

\section{Physical fitness}

Physical fitness is a status of general health, more specifically, the ability for the body to adapt to the external environment, it can be regarded as the body adapts to life or to sports and the environment (climate change, virus or other factors) comprehensive ability. Physical fitness is generally achieved through appropriate nourishment [13]. Physical fitness was defined as the ability to carry out the day's activities without exceeding weariness. However, with changes in lifestyles, nowadays, physical fitness is considered a measure of the body's capability to the effective functioning of work and leisure activities [14]. Muscular endurance is a health related component of physical fitness that relates to the ability of muscle groups to exert external force for many repetitions successive exertions [15].

Power is a skill related component of physical fitness that relates to the rate at which one can perform work [15].

Cardiorespiratory endurance is a health related component of physical fitness that relates to the ability of the circulatory and respiratory system to supple fuel during sustained physical activity and to eliminate fatigue products after supplying fuel [15]. 


\section{Methodology}

This research paper is analyzed by affinity diagram method and Analytic Hierarchy Process method. Help the decider analysis of the problem by the structural considerations, and achieve the purpose of solving problems, the following steps should be observed:

\section{Step 1. Affinity diagram method to collate facet selection}

The AHP paper first step is collecting 7 countries' recruitments and documents including Taipei, Taichung, Nantou, Tainan, Pingtung, Kaohsiung and yilan countries. And use the affinity diagram method sorted out three dimensions and eleven criteria.

\section{Step 2. Establishing analysis of hierarchy diagram}

Through the professional knowledge and the work experience of the experts, we regulated the garbage man collection's item. At this time, the experts consider to make the criteria become more independent to reduce the related of the decision factors, so it Complete compliance with Analytic Hierarchy Process's assumptions. The framework of the evaluating indexes for Taiwan's garbage man selection system is showed as Figure 1.

\section{Step 3. Design questionnaires}

Design questionnaires use Ordinal Scale, divided in 5 Item which is equally important, slightly important, quite important, very important, and absolutely important. Also, gives the measure of the value of $1,3,5,7$, and 9 . Between 5 basic dimensions and gives a measure of the value of 2, 4, 6, and 8.

According to the chart 1 decision Hierarchy for garbage man selection system, and design the interview form by Pair wise comparison. Under the garbage selection system, first factor layer required 3 times paired comparison. Under the job attitude, consideration factors layer require 3 times paired comparison. Under the Garbage Treatment Knowledge, consideration factors layer require 10 times paired comparison. Under the physical fitness, consideration factors layer require 3 times paired comparison. A Total of paired comparisons are 19 times.

Expecting to interview two expert groups, which are Officials and experienced garbage man, total is eighteen people. Face to face interviews, every expert need to finish 19 times paired comparison form.

\section{Step 4. Establish an even comparison matrix}

Once the hierarchy for garbage man selection is built, the decision makers methodically evaluate the elements by comparing them to one another two at a time. Decision making is turn into a mathematical science. The following formula is applied to construct pair-wise comparison matrices:

$$
A=\left[\begin{array}{cccc}
1 & a_{12} & \cdots & a_{1 n} \\
1 / a_{12} & 1 & \cdots & a_{2 n} \\
\vdots & \vdots & & \vdots \\
1 / a_{1 n} & 1 / a_{2 n} & \cdots & 1
\end{array}\right]
$$

\section{Step 5. Calculate Priority Vector and Maximized Eigenvalue}

After the A pair-wise comparison matrix is built, calculate $\mathrm{W}$ Eigen-value vector through the Numerical Analysis. If $\lambda$ is the pair-wise comparison matrix A's Eigen-value, $W$ will be A's Eigen-value vector.

$$
(\mathrm{A}-\lambda \mathrm{I}) \cdot \mathrm{W}=0
$$


Maximum Eigenvalue $\lambda$ max's approximate computation is A pair wise matrix multiplied with the priority vector $\mathrm{W}$ to obtain a vector $\mathrm{W}^{\prime}$. Then, each element in $\mathrm{W}^{\prime}$ divided by each element in priority vector W. Finally, the result of the value to strike an Arithmetic Mean then can get the maximum Eigen-value $\lambda \max$, the mathematical formula is as follows:

$$
\mathrm{A} \cdot \boldsymbol{W}=\boldsymbol{W}^{\prime}
$$

$\lambda_{\max }=(1 / n) *\left(W_{1}^{\prime} / W_{1}+\ldots W_{n}^{\prime} / W_{n}\right)$

\section{Step 6. Check the Consistence Index, C.I. )}

Consistency Index (C.I.) main function is to measure the project's answer whether a consistency or not. Saaty [16] suggested that C.I. $\leqq 0.1$ is an allowable error. The formula is as follows:

$$
\text { C.I. }=\frac{\lambda_{\max }-n}{n-1}
$$

Wherein the $\lambda$ max: maximum characteristic value, $\mathrm{n}$ is the order of the matrix.

\section{Step 7. Calculate overall total priority level and vector}

If the whole hierarchical structure's C.I. achieve an acceptable level, using the weighted average method to integrate each hierarchy elements' relatively weight to obtain the total priority vector of the whole hierarchy.

\section{Data analysis}

In this study, using analytic hierarchy process (AHP) decision model, planning a questionnaire for garbage man selecting item, and the result of interviews consistence index value are less than 0.1 , which means the experts have the same selecting standard are quite the same. Table 1 shows the hierarchical analysis method calculates the criteria weights of selection system for the garbage man selection system.

The experts who were interviewed are regarding to the importance of garbage man selection's factors. Officials consider that job attitude (0.415) is the most important dimension, next is physical fitness (0.297), and the worst is Garbage Treatment Knowledge (0.288). The experienced garbage man consider that the job attitude (0.478) is the most important dimension, next is Garbage Treatment Knowledge (0.310), then is physical fitness (0.212).

Further discuss from the officials group, investigate under job attitude's criteria. According to the table 1 , the most important criteria is "positive attitude"(0.425). Second, "enthusiasm"(0.350), and last is "righteous" (0.225); Discussion criteria of Garbage Treatment Knowledge, Resource recycling have the highest weight (0.314) from the officials. Second, is food waste recycling $(0.265)$. Third, is import and export of industrial waste $(0.180)$, fourth, is waste management $(0.165)$, then the last is introduction to ironmental science (0.076).

Next, we are going to discuss under criteria of physical fitness. The highest weight is muscular endurance (0.422), then is cardiorespiratory endurance (0.346), Final is muscular Power (0.232).

From the experienced garbage man's point of view, under job attitude, the most important criterion is "positive attitude"(0.480). Then is "Enthusiasm" and "Righteous" (0.260). Comparing the criteria of Garbage Treatment Knowledge, the most important criterion is "Waste management"(0.246). Then, is Introduction to Environmental science (0.210). Third, is resource recycling (0.203). Fourth, is food waste recycling (0.198). Final, is Import and export of industrial waste (0.143). Under the criteria of physical fitness, muscular Endurance got the highest weight (0.529) from the experienced garbage 
man. Then, is Cardiorespiratory endurance (0.370). Last, is muscular power (0.102).

\section{Discussion and Conclusions}

In Taiwan, no matter you want to apply a noise pollution Inspector or water quality inspector or garbage man are use the same selection system, also the written examination is the same. However, the different type of job should have the different professional knowledge and different selection system which is the authors' idea of the research problem. Using the same selection system to recruit different position, and the position Professionalism and personnel of suitability will drop sharply. Through using the analytic hierarchy process to discuss about the "garbage man selection system", the author found out the comparison of the three dimensions, which are job attitude, garbage treatment knowledge, and physical fitness. Two expert groups think that the job attitude is more important than others. Especially, the experienced garbage man's coordination weighted number is the most apparently, so we can know the experienced garbage man think that job attitude is the most important than others. And garbage man should have a great job attitude and great physical fitness, which is the same opinion with the officials. If a garbage man wants to have a great job attitude, officials must offer some great policies, and a positive work environment.

Under the job attitude, officials and experienced garbage man are considerable emphasis on positive attitude. Because have a positive attitude, the people are serviced will feel happy and positive energy. So, the garbage man will brings out the happiness and energy to the communities.

Move up to the next discussion, under the garbage treatment knowledge. Officials think that resource recycling is the most important criteria. Because effective waste recycling not only can avoid to destroyed our environment also can achieve sustainable environmental. But experienced garbage men think that waste management is the most important sub criteria. People often throw litter out in any public space which not only occupy space and also will cause rot, and malodorous, etc. So, if have an effective waste management to deal with the litter, it will solve the problem above.

Finally, under the physical fitness' dimension. Officials and Experienced garbage man think that muscle resistance capability is the most important criteria. Actually, garbage man's work is help the people throw the trash on the trash car, and the garbage man need to continue to throw the trash until the work is done, so they must have a great muscle resistance capability. At the same time, two groups of experts think the second important criteria is cardiovascular function. Because garbage man's work time is quite long, so need to have a great cardiovascular function to carry their job.

During the selection of garbage man, not only consider requirement of the selection criteria set by the officials but considerate the requirements from the Experienced garbage man. If officials set the criterion without considerate the requirements from the experienced garbage man, then the new garbage man's capacities will not completely match to the work. Only consider the garbage man's requirements when the officers set up criterions, cooperate with both sides, and establish a nice garbage man selection system. As a result, the garbage man selected by this system will have enough professional knowledge, right attitude, and outstanding physical fitness. Moreover, the garbage man will make more efforts to dedication to the work. And the benefit will go to cities and communities.

\section{References}

1. Pellow, D.N. (2002). Garbage Wars: The Struggle for Environmental Justice in Chicago. MIT press.

2. Chu, P.Y., and Chiu, J.F. (2003). Factors Influencing Household Waste Recycling Behavior: Test of an integrated Model. Journal of Applied Social Psychology 33(3):604-626.

3. McKenna, E. and Beech, N. (1995). Essence of Human Resource Management. Prentice Hall press.

4. Robbins, S.P. (2001), Organizational behavior, Prentice Hall press.

5. Organization for Economic Co-operation and Development (OECD). http://www.oecd.org/ 
6. Welford, R. and Starkey, R. (1996). Business and the Environment: A Reader. Routledge press.

7. International solid waste Association (ISWA)

https://www.cleanup.org.au/PDF/au/cua_recycling_fact_sheet.pdf

8. Australian environmental conservation organization

https://www.cleanup.org.au/PDF/au/cua_recycling_fact_sheet.pdf

9. Hong Kong Environmental Protection Agency(EPD)

10. Velnampy, T. (2008). Job Attitude and Employees Performance of Public Sector Organizations in Jaffna District, Sri Lanka. GITAM Journal of Management 6 (2): 66-73.

11. Judge, T.A and Kammeyer-Mueller, J.D. (2012). Job Attitudes. Annual Review of Psychology 63(1):341-367.

12. Robbins, S.P. (2001). Organizational Behavior: Leading and Managing in Australia and New Zealand. 3nd ed. NJ: Prentice Hall press.

13. Tremblay, M.S., Colley, R.C., Saunders, T.J., Healy, G.N. and Owen, N. (2010) Physiological and health implications of a sedentary lifestyle. Applied Physiology, Nutrition, and Metabolism 35 (6): 725-740.

14. President's Council on Fitness, Sports \& Nutrition's Science Board. http://www.fitness.gov/resource-center/elevate-health/

15. Corbin, C.B. and Dowell, L.J., (1978). Concepts of physical education with laboratories and experiments. Dubuque Publishers.

16. Saaty, T.L. (2008). Decision making with the analytic hierarchy process. International Journal Services Sciences, 1(1):83-98. 


\section{Goal Dimensions Criteria}

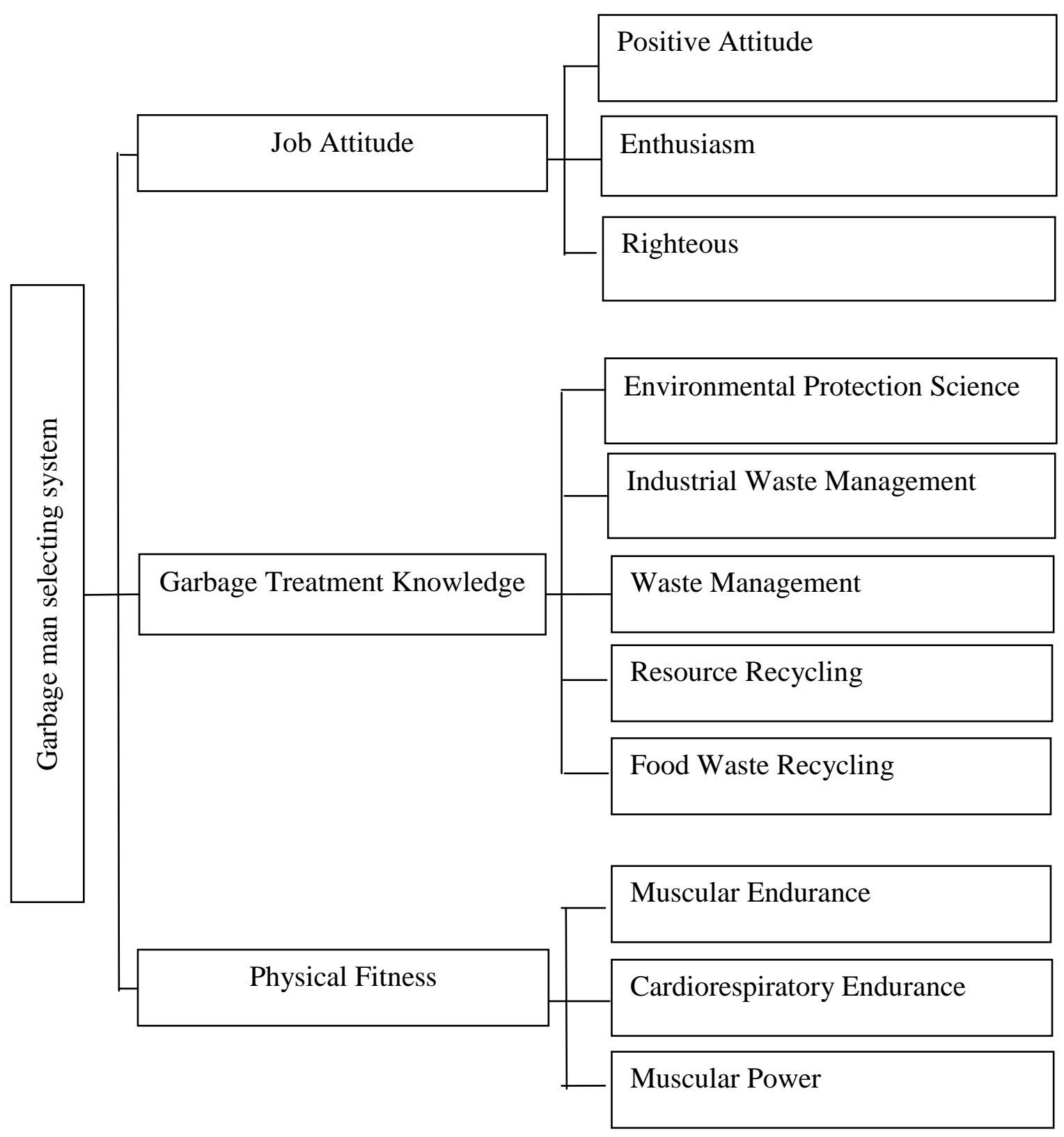

Figure 1 The hierarchical structure for Taiwan's Garbage man selecting system 
Table 1. Weights of dimensions and criteria for each group.

\begin{tabular}{lccc}
\hline $\begin{array}{c}\text { Dimensions } \\
\text { Criteria }\end{array}$ & Officials & $\begin{array}{c}\text { Experienced } \\
\text { garbage man }\end{array}$ & Average \\
\hline Job attitude & $\mathbf{0 . 4 1 5}$ & $\mathbf{0 . 4 7 8}$ & $\mathbf{0 . 4 4 7}$ \\
Positive Attitude & 0.425 & 0.480 & 0.452 \\
Enthusiasm & 0.350 & 0.260 & 0.305 \\
Righteous & 0.225 & 0.260 & 0.242 \\
Garbage Treatment Knowledge & $\mathbf{0 . 2 8 8}$ & $\mathbf{0 . 3 1 0}$ & $\mathbf{0 . 2 9 9}$ \\
Environmental Protection science & 0.076 & 0.210 & 0.143 \\
Industrial Waste management & 0.180 & 0.143 & 0.161 \\
Waste Management & 0.165 & 0.246 & 0.205 \\
Resource Recycling & 0.314 & 0.203 & 0.259 \\
Food Waste Recycling & 0.265 & 0.198 & 0.232 \\
Physical Fitness & $\mathbf{0 . 2 9 7}$ & $\mathbf{0 . 2 1 2}$ & $\mathbf{0 . 2 5 4}$ \\
Muscular Endurance & 0.422 & 0.529 & 0.476 \\
Cardiorespiratory Endurance & 0.346 & 0.370 & 0.358 \\
Muscular Power & 0.232 & 0.102 & 0.167 \\
\hline
\end{tabular}

